\title{
The immune response and protective efficacy of a potential DNA vaccine against virulent Pasteurella multocida
}

\author{
Ahmed A. M. Yassein *iD, Ayaat A. Teleb, Gamal M. Hassan and Zaki A. El Fiky
}

\begin{abstract}
Background: Pasteurella multocida is the main cause of several infections of farm animals, and the immunity gained from commercial vaccines is for the short term only and needs to be routinely administered, so work on new vaccines against virulent $P$. multocida is crucial.

Results: In this study, the $\mathrm{OmpH}$ gene was amplified from ten P. multocida strains, and the PCR products were sequenced and analyzed. The results of RFLP analysis of OmpH gene digested by Msp/ enzyme showed that all of ten strains examined possessed one restriction site and two fragments, 350 and $650 \mathrm{bp}$. The $\mathrm{OmpH}$ sequence of strain No. 10 was cloned into bacterial expression vector pUCP24, and the recombinant pUCP24-OmpH was expressed in E. coli DH5a. Serum samples obtained from the ELISA test from a group of vaccinated rats indicate that the antibodies were present at high titer in immunized rats and can be tested as a vaccine candidate with a challenge.

Conclusions: In rats infected with the DNA vaccine and inactivated vaccine, a significant increase in serum antibody levels was observed. In addition, the DNA vaccine provided the vaccinated rats with partial protection; however, the protective efficacy was greater than that offered by the live attenuated vaccine. This successful recombinant vaccine is immunogenic and may potentially be used as a vaccine in the future.
\end{abstract}

Keywords: OmpH gene, PCR-RFLP, pUCP24-OmpH, DNA vaccine, Pasteurella multocida serotype a

\section{Background}

Livestock owners and crevice animals vaccinated with inactivated or destroyed vaccines have appropriate questions as to the extent of site reactions to the injection, with justified concerns as to the severity of injection site reactions. However, these ideas may become worries of the past, since DNA vaccines are not formulated with chemical adjuvants, the leading contributor to injectionsite reactions. Since DNA vaccines consist simply of nucleic acids, they lack the ability to replicate, infect, or induce disease [1].

DNA vaccination, or genetic vaccination, is the common name for methods of vaccination that cause

* Correspondence: aay00@fayoum.edu.eg

Genetics Department, Faculty of Agriculture, Fayoum University, 63514 Fayoum, Egypt

\section{Springer Open}

immunity by transfecting DNA encoding host cells with an antigen, rather than by injecting protein or peptide antigens. The immune response resulted from DNA vacination in animal host transfected cells was similar to traditional vaccines [2], it has been shown that DNA vaccines effectively bypass maternal antibody involvement [3] and that no anti-DNA antibodies are found [4]. A large number of experimental DNA-based veterinary vaccines have been evaluated in a number of species with varying degrees of immunological response and efficacy against challenge $[5,6]$.

Pathogenic strains of $P$. multocida allow the virulenceassociated genes to expression under host conditions. Many of these genes, particularly the OMP-encoding genes, have been extensively studied, and some have

(c) The Author(s). 2021 Open Access This article is licensed under a Creative Commons Attribution 4.0 International License, which permits use, sharing, adaptation, distribution and reproduction in any medium or format, as long as you give appropriate credit to the original author(s) and the source, provide a link to the Creative Commons licence, and indicate if changes were made. The images or other third party material in this article are included in the article's Creative Commons licence, unless indicated otherwise in a credit line to the material. If material is not included in the article's Creative Commons licence and your intended use is not permitted by statutory regulation or exceeds the permitted use, you will need to obtain permission directly from the copyright holder. To view a copy of this licence, visit http://creativecommons.org/licenses/by/4.0/. 
been used as the basis for the creation of vaccines that can heterologically protect against multiple strains of $P$. multocida from infection [7-9]. Some studies have shown that some outer membrane proteins (OMPs) of P. multocida have contributed to pathogenesis and possess immunogenic and bactericidal properties [10-14]. $\mathrm{OmpH}$, a porin, is a general transporter that allows diffusion of various molecules simpler [15]. Another research identified associations between $\mathrm{OmpH}$ alleles and capsular types of $83 P$. multocida isolates, and found variable $\mathrm{OmpH}$ alleles within capsular type A isolates [16]. $\mathrm{OmpH}$ is an antigenic, surface-exposed, and preserved OMP porin found in $100 \%$ of the bovine isolates investigated and mooted as a possible candidate for a vaccine [17].

The P. multocida toxin (PMT) DNA vaccine has the potential to protect infected animals from infections caused by $P$. multocida [18], while this DNA vaccine was able to provide protection against avian pasteurellosis by using two separate OMPs, OmpH and OmpA, and showed the highest degree of protection $[19,20]$. The pVAX1-ABA392 DNA vaccine is capable of producing a high titer of anti-HS antibodies caused by $P$. multocida and has the potential to be a vaccine candidate [21]. The aim of this study was therefore to characterize the nucleotide sequence of the $\mathrm{OmpH}$ gene using molecular genetics and bioinformatics techniques. In addition, a potential pUCP24 OmpH DNA vaccine should be developed and its protective efficacy evaluated.

\section{Methods}

\section{Bacterial strains and expression vector}

Pasteurella multocida strains used in this study were isolated and identified in previous study in our laboratory [22]. Escherichia coli DH5 $\alpha$ strain was obtained from Dr. Mercedes, Facultat de Farmacia, Barcelona, Spain. The expression vector pUCP24 was obtained from Novagen, (Germany) for cloning and gene expression.

\section{Amplification of $\mathrm{OmpH}$ gene and PCR-RFLP}

Genomic DNA from ten strains of P. multocida was isolated using the XS method [23]. Primers for amplification of major outer membrane protein $\mathrm{H}(\mathrm{OmpH})$ gene of $P$. multocida strains were designed according to the nucleotide sequences of the $\mathrm{OmpH}$ gene of $P$. multocida pm70 (NCBI accession number NC_002663). The $\mathrm{OmpH}$ gene was amplified using gene-specific oligonucleotide primers: OmpH-KpnI forward TGAGGTA CCATGAAAAAGACAATCGTAG and OmpH-EcoR1 reverse TAGGAATTCTTAGAAGTGTACGCGTAAAC. The PCR-amplified products were analyzed on $1.2 \%$ agarose gel and purified using a protocol described by Li et al [24]. With regard to RFLP banding patterns, each of PCR products (OmpH gene) was digested using BglII or MspI restriction enzymes (Thermo Scientific ${ }^{\mathrm{Ta}}$, ER0081 and ER0541, respectively), according to the manufacturer's instructions. Fragments were then analyzed in $2 \%$ agarose on $10 \%$ TBE under UV illumination. A molecular weight marker (1kb DNA ladder, Fermentus) was added for each of the gel runs.

\section{Sequencing of $\mathrm{OmpH}$ gene and phylogenetic analysis}

The purified $\mathrm{OmpH}$ gene PCR products were sequenced using an API 3730X1 Automated DNA sequencer (Applied Biosystems, USA). The sequence data were analyzed using the National Center for Biotechnology Information (NCBI) database using the BLAST. OmpH gene sequences from strain Nos. 2, 5, 7, and 10 were subjected to alignment with the sequences of $P$. multocida in the GenBank sequence database using the BLAST in program. Phylogenetic analyses were conducted according to Tamura et al. [25]. The MEGA 4 program was used to generate a phylogenetic tree using the UPGMA method.

\section{Construction of recombinant plasmids}

Each of OmpH gene PCR products and pUCP2 expression vector was digested using Kpn1/EcoR1 restriction enzymes, (Thermo Scientific ${ }^{\mathrm{Tm}}$ Fermentas, Germany, ER0521 and ER0271, respectively), according to the manufacturer's instructions. After purification, they were ligated in ligation mixture consisting of $5 \mu \mathrm{l}$ deionized water, $1 \mu \mathrm{l}$ pUCP24 expression vector, $2.5 \mu \mathrm{l}$ PCR product, $1 \mu \mathrm{l} \mathrm{T}$ ligase buffer, and half microliter of $\mathrm{T}_{4}$ ligase enzyme. Then, they were kept in a microfuge tube and spun for a few seconds. The vial was incubated at $22{ }^{\circ} \mathrm{C}$ for $2 \mathrm{~h}$; then, the ligation mixture was ready for transformation.

\section{Transformation of E.coli competent cells}

Competent cells of $E$. coli DH5 $\alpha$ were transformed using rapid transformation procedure (Life Technologies Corporation 2013) as user guide: E.coli competent cells were taken from a $-80{ }^{\circ} \mathrm{C}$ freezer in $1.5-\mathrm{ml}$ tube and kept on ice. Five microliters containing $50 \mathrm{ng}$ of recombinant plasmid DNA (circular) was added to $50 \mu \mathrm{l}$ competent cells and incubated on ice for $10 \mathrm{~min}$. Tubes were transferred to water bath at $42{ }^{\circ} \mathrm{C}$ for $45 \mathrm{~s}$ and then back on ice for $2 \mathrm{~min}$ to reduce damage to the cells. One milliliter of LB antibiotic-free medium was added, and tubes were incubated for $1 \mathrm{~h}$ at $37^{\circ} \mathrm{C}$ in a shaking water bath (200rpm). One hundred microliters of the resulting culture was spread on LB plates with antibiotic (ampicillin) and colonies picked after about $12-16 \mathrm{~h}$. 


\section{Vaccination protocol}

Forty male albino rats weighing $90-110 \mathrm{~g}$ (8-10 weeks old) were obtained from the Egyptian Company for Production of Vaccines, Sera \& Drugs (EGYVAC), Helwan, Egypt. Rats were housed in universal polypropylene cages and kept in the animal house of the Biochemistry Department, Faculty of Agriculture, at $25 \pm 2{ }^{\circ} \mathrm{C}$ with $12 \mathrm{~h}$ of continuous fluorescent lighting. Animals fed a standard synthetic diet were obtained from Feedmix Company in Cairo and had free access of tap water, ad libitum. Rats were kept for 1 week for adaptation, before starting the experiment. Rats were divided into four groups equal in weight (ten rats each). The rats were assigned randomly to four groups, i.e., (1) the control group, (2) inactivated vaccine group, (3) the DNA vaccine (pUCP24-OmpH) group, and (4) the pUCP24 group. The rats in the control group were injected with $100 \mu \mathrm{l}$ PBS $(0.01 \mathrm{M}, \mathrm{pH} 7.2)$, the rats in group 2 were injected with $100 \mu \mathrm{l}$ inactivated vaccine, the rats in group 3 were injected with $100 \mu \mathrm{g} / 100 \mu \mathrm{l}$ of recombinant plasmids isolated from transformed bacteria, and the rats in group 4 were injected with $100 \mu \mathrm{g} / 100 \mu \mathrm{l}$ of vector (pUCP24).

\section{Detection of serum antibody levels}

After immunization, blood samples were drawn from the rats, and serum samples were collected from the immunized rats at $0-, 14-$, and 28 -day post-vaccination. The serum antibody titers were tested using indirect enzyme-linked immunosorbent assay (ELISA) [26].

\section{Challenge study}

Each group of experimental containing ten apparently healthy rats were challenged by inoculating intraperitoneally after 10 days of the 2nd DNA immunization with $0.1 \mathrm{ml}\left(10^{6} \mathrm{CFU}\right)$ of virulent $P$. multocida type $A$, and returned to their cages. Rats were fed with pelleted feed and water ad libitum before and during the experiment. All experimental rats were kept under the same environment. Clinical and postmortem examination was conducted on any rat that died, and the lungs were collected for histopathological tests and re-isolation of $P$. multocida. The survival number and protection rate were counted. Diethyl ether was used for animal anesthesia before samples were taken for histopathological studies.

\section{Results}

\section{Amplification and RFLP of $\mathrm{OmpH}$ gene}

The target gene fragments were amplified using the genomic DNA of ten P. multocida strains as a template. PCR amplification of the OmpH gene yielded the expected product of $1030 \mathrm{bp}$. A single PCR product with a similar molecular size was obtained from each strain (Fig. 1). The results of RFLP analysis of $\mathrm{OmpH}$ gene digested by $M s p I$ and BglII restriction enzymes are presented in Figs. 2 and 3, respectively. Digestion of $\mathrm{OmpH}$ gene with $M s p I$ enzyme showed that all of the ten strains examined possessed one restriction site and two fragments, 350 and 650 bp (Fig. 2). Whereas BglII enzyme digestion of $\mathrm{OmpH}$ gene divided the strains into two groups, four out of ten strains showed a restriction site producing two fragments, 250 and $800 \mathrm{bp}$, and the rest of the strains had one band, 1000 bp (Fig. 3).

\section{Sequencing of $\mathrm{OmpH}$ gene and phylogenetic analysis}

Single-fragment nucleotide sequences from each PCR product of $\mathrm{OmpH}$ gene amplified from strain Nos. 2, 5,7 , and 10 were sequenced and analyzed using DNASTAR (DNASTAR Inc., Madison, WI) and MEGA4 programs [25]. The multiple sequence alignment reveals the high identity of these four $\mathrm{OmpH}$ sequences to other $P$. multocida $O m p H$ sequences in the GenBank database. The topology of the neighbor-

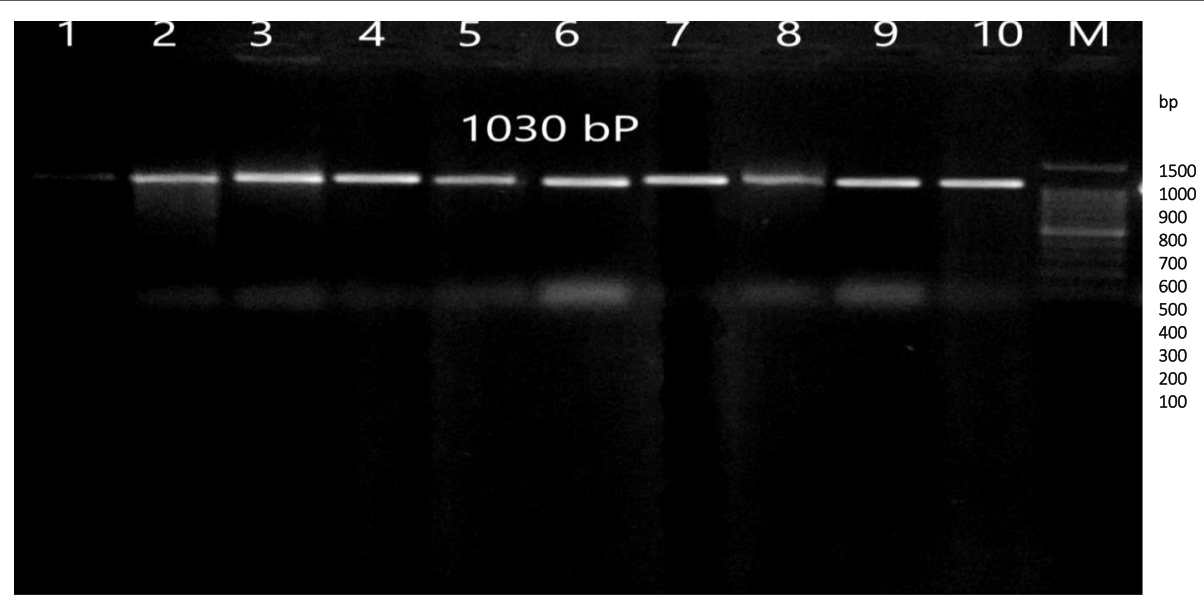

Fig. 1 Agarose gel electrophoresis of ten strains of OmpH gene of Pasteurella multocida. Lanes 1-10 PCR product and M 100 bp DNA ladder 


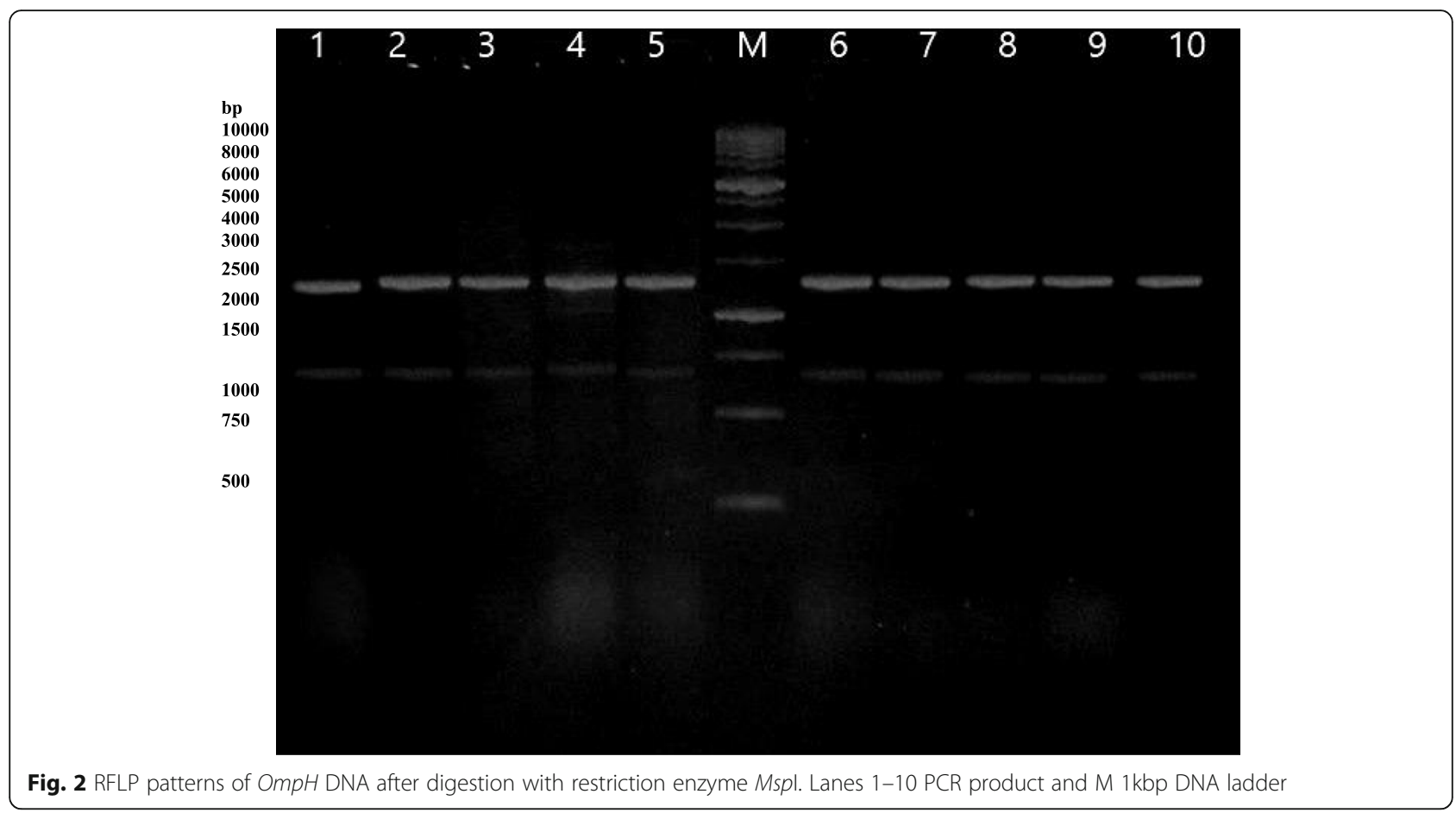

joining tree represented a monophyletic group (Fig. 4). The phylogenetic tree revealed that these four sequences were closed related to the P. multocida OmpH gene sequences obtained fron GenBank. The tree was successfully grouped into two main clusters. The $\mathrm{OmpH}$ DNA sequences of strain Nos. 2, 5, 7, and 10 closed in the first cluster with three $P$. multocida strain serotype A: U50907 strain X-73, KY403515 strain PM/VSVRI/2015, and
KY403514 strain PM/VSVRI/2004. Moreover, strain No. 10 was closed with the latest two strains. In addition, the second cluster consisted of closed 14 GenBank accessions (Fig. 4).

\section{Confirmation on recombinant clone}

The purified PCR products of the OmpH-EcoR1/Kpn1 gene were cloned into the pUCP24 vector digested with

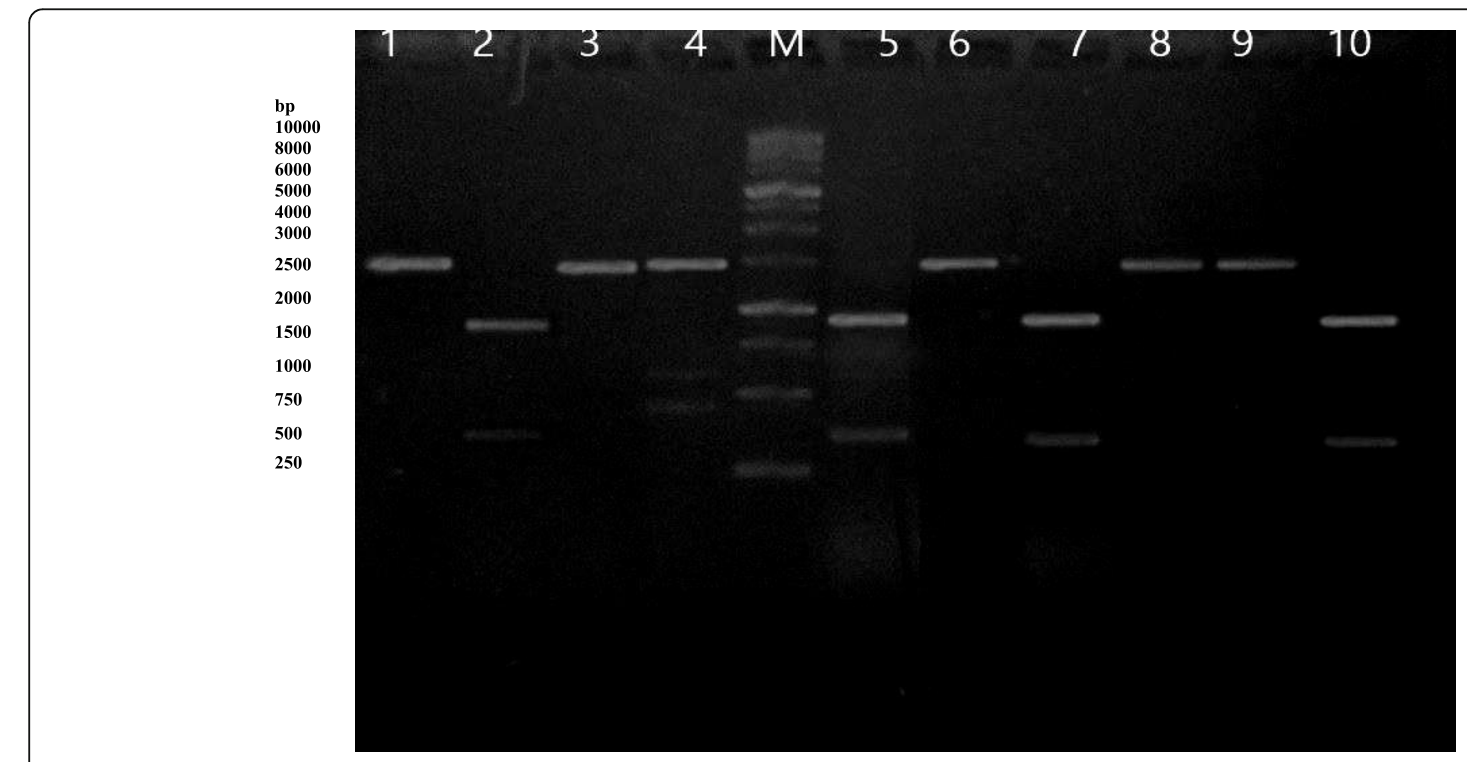

Fig. 3 RFLP patterns of OmpH DNA after digestion with restriction enzyme Bg/ll. Lanes 1-10 PCR product and M 1kbp DNA ladder 


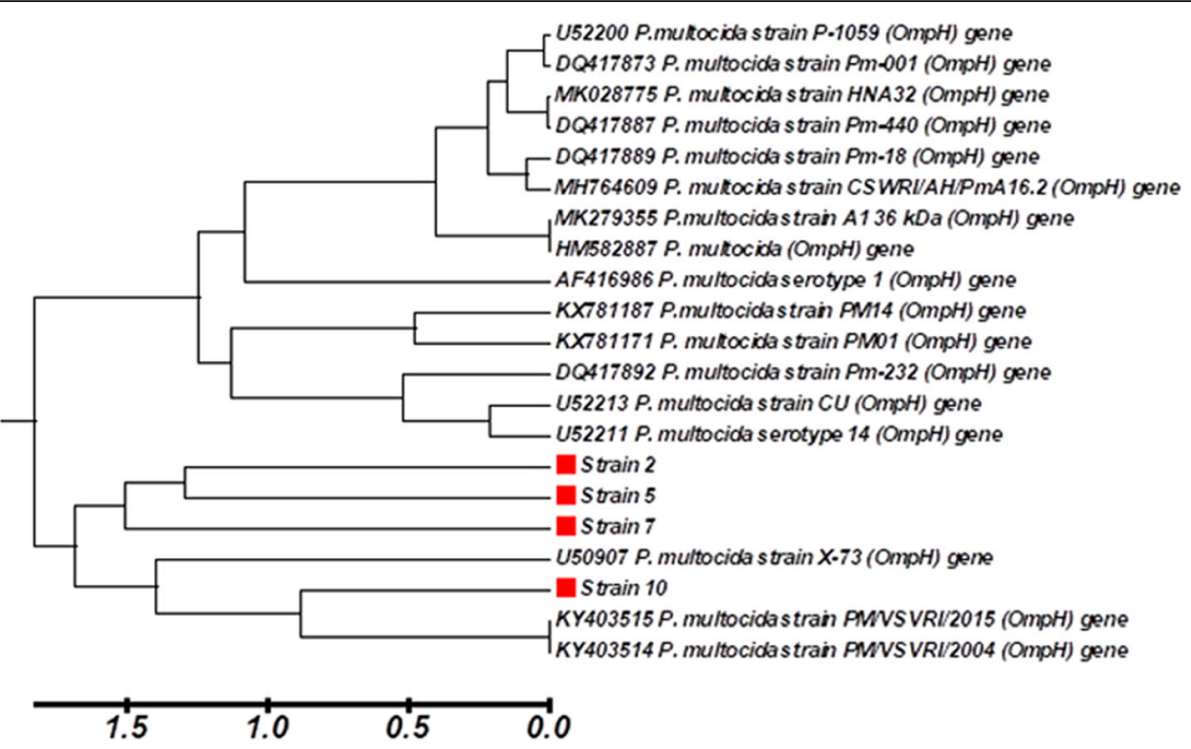

Fig. 4 Neighbor-joining phylogenetic tree of $\mathrm{OmpH}$ gene from P. multocida strain Nos. 2, 5, 7, and 10 with different nucleotide sequences of Pasteurella multocida $\mathrm{OmpH}$ gene

EcoR1/Kpn1. The mixture of ligation was then transformed into competent E. coli DH5 $\alpha$. The recombinant clones of $\mathrm{OmpH}$ gene into pUCP24 vector were successfully carried out. The recombinant pUCP24-OmpH plasmid was confirmed via agarose gel electrophoresis as shown in Fig. 5, and affirmed the size of the pUCP24$\mathrm{OmpH}$ recombinant plasmid at 5000bp meanwhile the non-insert vector size at $4035 \mathrm{bp}$. These recombinant plasmids were used to study the development of DNA vaccine and its protective efficacy.

\section{Immunogenicity determination and challenge}

The results of immune responses against inactivated and DNA vaccines (pUCP24-OmpH) in Fig. 6 shows that, after the first immunization of rats, the DNA vaccine group had higher significant levels $(P<0.05)$ of serum

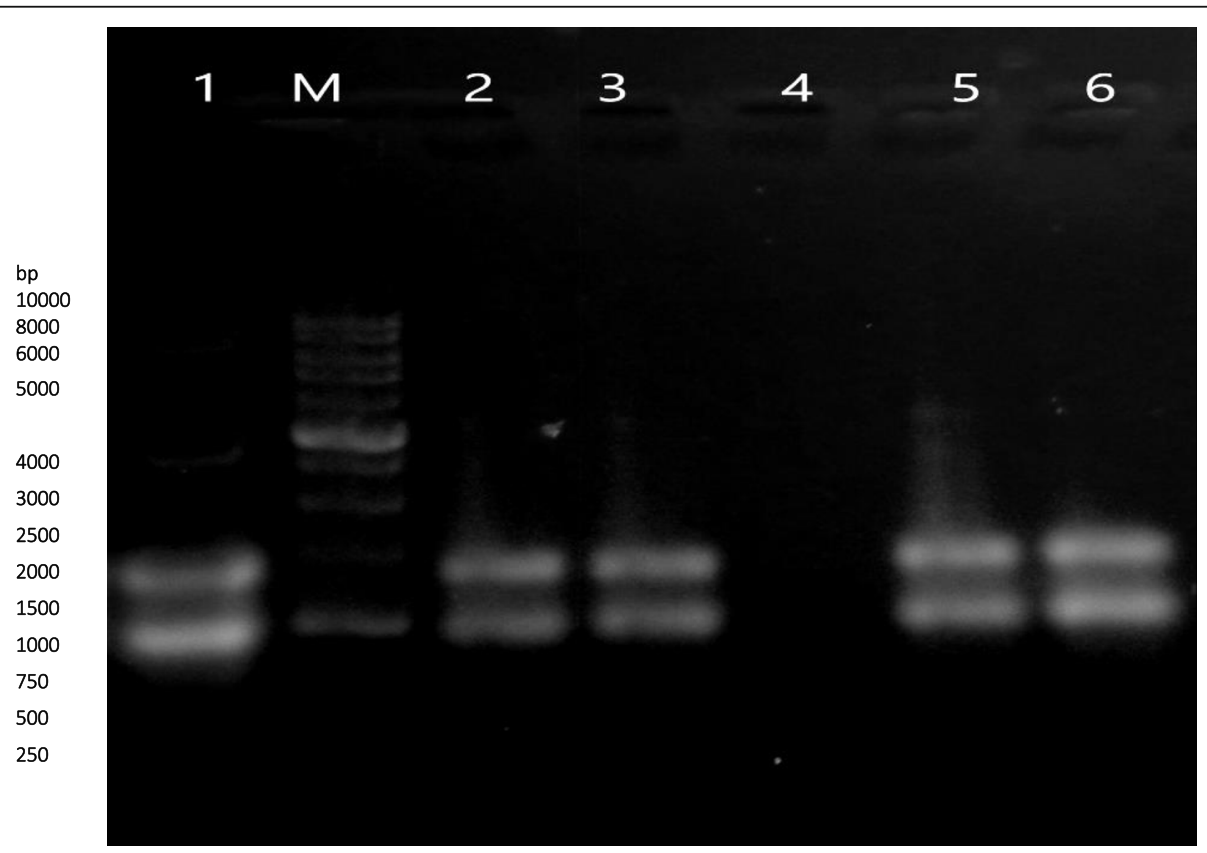

Fig. 5 Agarose gel electrophoresis for plasmid DNA purified from recombinant clones of E. coli DH5a. Lane 1 pUCP24 vector; M 1 kbp DNA ladder; lanes 2, 3, 5, and 6 recombinant plasmid (pUCP24-OmpH) for strains 3, 4, 6, and 7 respectively; and lane 4 negative control 


\section{$\lg M$}

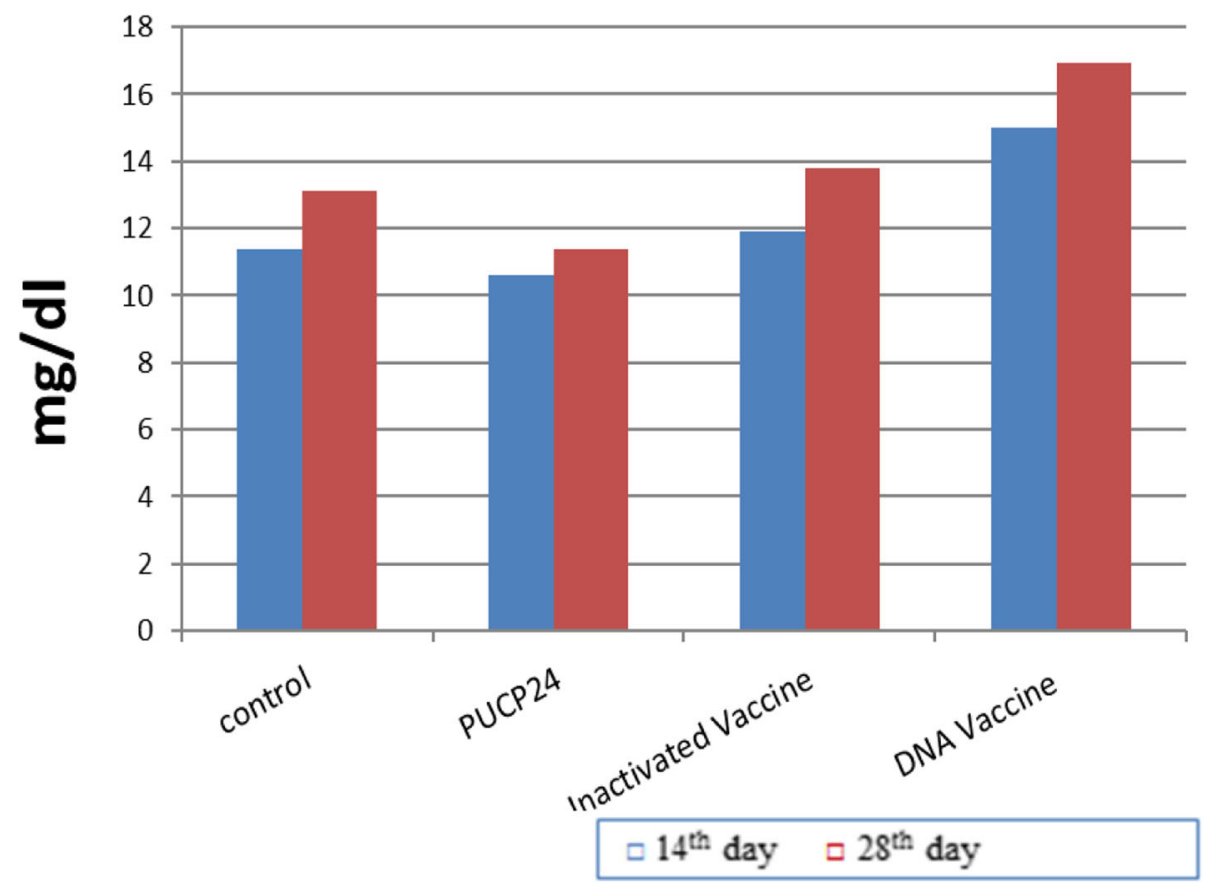

Fig. 6 Serum IgM responses in immunized rats measured by indirect ELISA at the 14th day and 28th day of post-immunization. Each bar represents the mean O.D. \pm standard error of five pooled serum samples

antibody IgM compared to the other groups (PBS, inactivated vaccine, and pUCP24 groups). In the second immunisation, the DNA vaccine group had the highest significant value of IgM, while the pUCP24 group had the lowest, despite the fact that DNA vaccine had a numerical increase in IgM value as compared to PBS and inactivated vaccine groups. In addition, there is a significant increase in IgG value of DNA vaccine after first immunization compared to the PBS and pUCP24 groups but not with the inactivated group as shown in Fig. 7, and IgG value of inactivated vaccine did not differ significantly with PBS and pUCP24 groups. However, after the second immunization, the DNA vaccine and inactivated

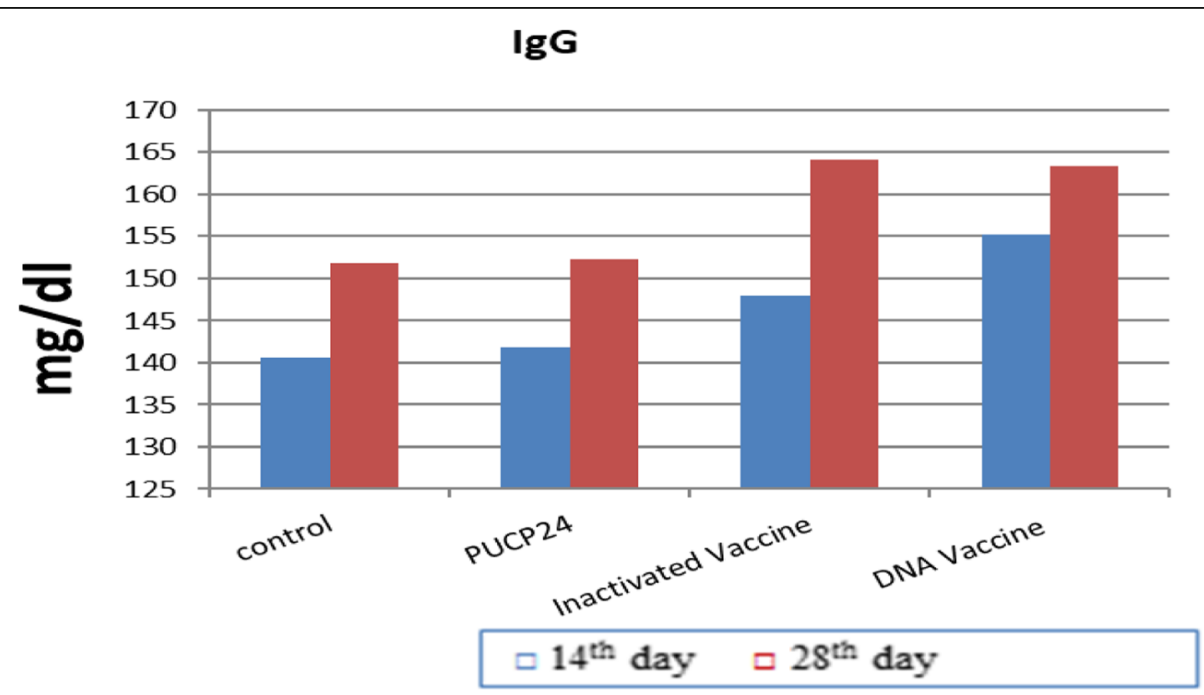

Fig. 7 Serum lgG responses in immunized rats measured by indirect ELISA at the 14th day and 28th day of post-immunization. Each bar represents mean O.D. \pm standard error of five pooled serum samples 
vaccine groups had the highest values of IgG compared with PBS and pUCP24 groups.

Ten days after the last vaccination, four groups of rats were exposed to virulent $P$. multocida serotype A. The rats in the control group began to die the second day after the challenge. None of the rats in the control group survived more than 4 days after the challenge. No rats died in the DNA vaccine group or the inactivated vaccine group within 6 days after the challenge. Rats in the inactivated vaccine group began to die on the 7th day, and the number of surviving rats remained unchanged from the 8th day onwards. In the pUCP24 group, death occurred between days 4 and 7 , and from then on, the number of surviving rats did not decrease further. Clinical signs manifested prior to death included weakness, inappetence, dyspnea, ataxia, and epistaxis. Postmortem findings recorded included congested lungs (Fig. 8). Frothy exudates were noticed in the lung of rats inoculated with $P$. multocida of serogroup A at a concentration of $10^{8} \mathrm{CFU}$. Rats in group 4 which were vaccinated with DNA vaccine exhibited clinical mortality.

\section{Vaccine efficacy}

Groups of rats were challenged with virulent avian $P$. multocida serotype A at a concentration of $10^{6} \mathrm{CFU} 10$ days after the last immunization. Survival number and protection rate were counted until 14 days. The results in Table 1 show that the No. of death in pUCP24 and PBS groups was higher than the two DNA vaccines and the inactivated vaccine. However, the survival of rats immunized with inactivated vaccine $(70 \%)$ was lower than those in the rats immunized with the DNA vaccine (90\%). The mortality of rats injected with PBS was 100\% after challenge whereas that of the pUCP24 group was $70 \%$. In the DNA vaccine group, the relative protection rate was higher than in the inactivated group.

\section{Discussion}

Identification and characterization of important immunogens of the bacteria not only would help in designing an improved vaccine but also would help in developing the protection status of vaccinated animals. The OMPs of $P$. multocida are possible inducing immunogens for cattle [27]. Pati et al. [28] reported that OMP was immunogenic in buffalo calves and suggested that they could be used as a vaccine against hemorrhagic septicemia (HS). Many gram-negative bacteria have one or more predominant outer membrane proteins, and it has been shown that these proteins play an important role in host-pathogen interactions and disease processes such as $O m p A$ and $O m p H$ [29]. This study aimed to perform purification and expression of the major outer membrane gene $(\mathrm{OmpH})$ of $P$. multocida strains isolated from Egypt and identified by Hassan et al. [22]. The results of PCR amplifying a product of the expected size of 1030 bp and a single PCR product with a similar molecular size were obtained from each strain reflecting the conserved nature of the $\mathrm{OmpH}$ gene among the $P$.
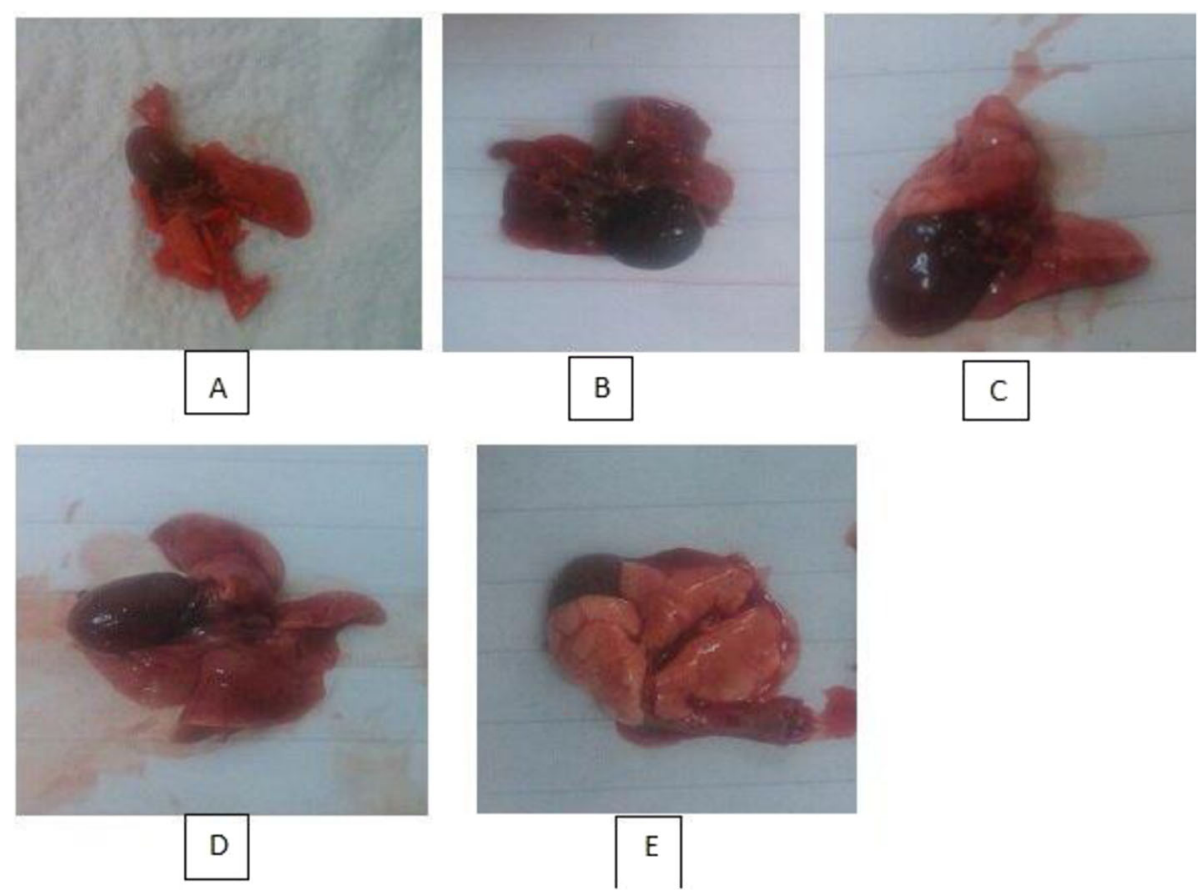

Fig. 8 Photographic lesions in lungs of rat groups: A negative control, B PBS group, C pUCP24 group, D inactivated vaccine, and E DNA vaccine 
Table 1 Vaccine protective efficacy over 14 days in rats challenged with Pasteurella multocida Type A

\begin{tabular}{lll}
\hline Groups & Survival number/total rats & Mortality\% \\
\hline Group 1 (PBS) & $0 / 10$ & 100 \\
Group 2 (inactivated vaccine) & $6 / 10$ & 40 \\
Group 3 (pUCP24) & $4 / 10$ & 60 \\
Group 4 (recombinant DNA vaccine) & $9 / 10$ & 10 \\
\hline
\end{tabular}

multocida serotypes. The same results were reported by many researchers [30-33]. In addition, $\mathrm{OmpH}$ is highly conserved among $P$. multocida serotypes and is the only $P$. multocida protein where a small number of gene fragments are similar to eukaryotic cilia or flagella [11, 34].

The significance of PCR-RFLP types in the variation of virulence and other phenotypic characters among the $P$. multocida isolates remained to be elucidated [25]. In this research, PCR-RFLP is used for identifying the variability on the OmpH gene of $P$. multocida. Our results showed that $B g l \mathrm{II}$ restriction endonuclease is useful for identifying variability of banding pattern and concluded that PCR-RFLP was a rapid test and could be done for selecting a different $\mathrm{OmpH}$ gene amplified from strain Nos. 2, 5, 7, and 10. The PCR analysis based on RFLP in $\mathrm{OmpH}$ gene is widely applied for the genetic classification of avian P. multocida isolated [30, 33] and for analyzing polymorphism within a gene segment $[33,35]$.

In this study, the OmpH gene of P. multocida, strain Nos. 2, 5, 7, and 10, was sequenced and analyzed. The sequence analysis indicated that $P$. multocida strains share maximal nucleotide identities ( $>90 \%)$ with avian $P$. multocida strains in the GenBank database in agreement with another study [32, 33, 36, 37]. Despite the similarity of the $\mathrm{OmpH}$ gene size amplified from the ten strains and the PCR-RFLP banding patterns of four strains, the phylogenetic tree showed the $O m p H$ sequences of strain Nos. 2, 5, 7, and 10 were closed in the first cluster. Moreover, strain No. 10 was closed with two P. multocida strains KY403515 strain PM/VSVRI/2015 and KY403514 strain PM/VSVRI/2004; Abbas et al. [33] reported that the phylogenetic dendrogram of $\mathrm{OmpH}$ nucleotide sequence amplified from these strains showed that PM/VSVRI/2015 was clustered with PM/VSVRI/ 2004. The vaccine strain (PM/VSVRI/2004) was characterized and identified as PM type A and that used in FC vaccine ${ }^{\circ}$. Therefore, we select the $\mathrm{OmpH}$ gene amplified from strain No. 10 to construct a recombinant DNA vaccine.

Bacterial porin genes are sometimes difficult to clone in $E$. coli because external porins are usually lethal for $E$. coli. Initial attempts to clone the entire $\mathrm{OmpH}$ gene into the expression vector were unsuccessful by a number of workers $[11,15]$. Non-succeed refers to the leaking expression of the primary protein without IPTG induction, and lethality of recombinant porin protein in E. coli. In this study, we cloned the $\mathrm{OmpH}$ gene into expression vector pUCP24, and the recombinant pUCP24-OmpH was expressed in E. coli DH5 $\alpha$. In similar studies, Luo et al. [15] cloned the $\mathrm{OmpH}$ gene of P. multocida X-73 into expression vector pQE30, and Singh et al. [38] cloned the PCR product of $\mathrm{OmpH}$ gene of $P$. multocida P52 into $\mathrm{PQE} 32$ expression vector, whereas the P. multocida OmpH was cloned in pET32a, and $\mathrm{rOmpH}$ was expressed in E. coli BLELISA (DE3) [32].

Immunogenicity and pathogenicity studies of various derivatives, components, and clones have been tested to find suitable immunization for P. multocida $[39,40]$. Immunizations with genomic expression libraries has emerged as a novel technology [41, 42]. For identifying candidate vaccine genes that provide protection against pathogens, some studies have identified individual protective genes via the sequential fractionation of cDNA or genomic expression libraries [21, 43, 44]. The potential of $\mathrm{OmpH}$ gene as a vaccine candidate has been described and carried out in mice model against $P$. multocida. Thus, this study was conducted to analyze the immunogenicity from the pUCP24-OmpH recombinant clone. Sthitmatee et al. [45] suggested that serotyped $O m p H$ proteins are strongly homologous and cross-protected. Other studies have also demonstrated that $\mathrm{OmpH}$ can induce high-level immune responses to homologous bacteria $[35,37,46]$.

On the other hand, the serum obtained from vaccinated groups, positive control (killed bacterium), pUCP24 vector, and negative control (normal saline) provided results from ELISA showed positive results. ELISA was used to compare the immune response of mice to a $P$. multocida vaccine grown in the presence of serum to a splenocyte suspension [47]. The presence of IgG antibody from the serum of rats immunized with pUCP24-OmpH recombinant clone indicates a substantially higher antibody, thereby suggesting this DNA vaccine has the potential to induce a cellular immune response when compared to the negative control group. The experimental conformation was the intranasal administration of $P$. multocida in rats. The pathological study showed acute bronchopneumonia, which is in agreement with other studies [48, 49]. Luo et al. [15] vaccinated chickens with $P$. multocida serotype A:1 native and recombinant $\mathrm{OmpH}$, and reported $100 \%$ and $18 \%$ safety, respectively. However, Sthitmatee et al. [45] 
showed that both the A:1 serotype native and recombinant $O m p H$ have the same protein [13]; immunized mice with recombinant $\mathrm{OmpH}$ from $P$. multocida serotype B:2 causing hemorrhagic septicemia and obtained $100 \%$ protection against $P$. multocida at the same time as mice immunized subcutaneously, and challenged intraperitoneally only resulted in $80 \%$ protection. Moreover, recombinant $\mathrm{OmpH}$ from $\mathrm{P}$. multocida (swine isolate) causing atrophic rhinitis resulted in $70 \%$ protection in mice [11]. Dabo et al. [17] used recombinant OmpA from a bovine isolate of $P$. multocida serotype A:3 to vaccinate mice, but no protection was obtained.

DNA vaccines are known as fourth-generation vaccines and were introduced to counter infection due to Pasteurella as it is cheaper compared to other types of vaccines in veterinary use [50]. There were few DNA vaccine against Pasteurellosis developed using different genes. DNA vaccine using $P$. multocida toxin (PMT) gene has the potential to protect an infected animal against infections caused by $P$. multocida [18].

\section{Conclusion}

This study shows that the pUCP24-OmpH recombinant clone was successfully expressed and stable in E. coli DH5 $\alpha$ host cells. We have shown that the DNA vaccine is capable of producing a high titer of antibody against P. multocida. Between all vaccinated rats, there is no lesion or inflammation detected and this may be used as a vaccine in the future.

\section{Abbreviations \\ BLAST: Basic Local Alignment Search Tool; cDNA: Complementary DNA; CFU: Colony-forming unit; ELISA: Enzyme-linked immunosorbent assay; HS: Hemorrhagic septicemia; IgG3: Immunoglobulin G; IgM: Immunoglobulin M; NCBI: National Center for Biotechnology Information; OmpH: Outer membrane protein H; OMPs: Outer membrane proteins; PBS: Phosphate- buffered saline; PCR: Polymerase chain reaction; PMT: P. multocida toxin; RFLP: Restriction fragment length polymorphism}

\section{Acknowledgements}

Not applicable for this section.

\section{Authors' contributions}

A.A.M.Y., A.A.T, G.M.H., and Z.A.E. designed research; A.A.T was aware of the group allocation at different stages of the experiment; A.A.M.Y., A.A.T, G.M.H., and Z.A.E. conducted review and editing; all authors participated in the data analyses and discussion, and A.A.M.Y., G.M.H., and Z.A.E. wrote the paper. The authors read and approved the final manuscript.

\section{Funding}

Not applicable for this section.

\section{Availability of data and materials}

The data used and/or analyzed during the current study available from the corresponding author on reasonable request.

\section{Declarations}

\section{Ethics approval and consent to participate}

The study was approved by the Ethical Committee of the Fayoum University (Permission number 6200, 2011). The work has been carried out in accordance with EU Directive 2010/63/EU for animal experiments.
Consent for publication

Not applicable for this section

\section{Competing interests}

The authors declare that they have no competing interests.

Received: 12 December 2020 Accepted: 14 May 2021

Published online: 31 May 2021

\section{References}

1. Drunen Littel-van den Hurk S, Braun RP, Lewis PJ, Karvonen BC, Baca-Estrada ME, Snider M, McCartney D, Watts T, Babiuk LA (1989) Intradermal immunization with a bovine herpesvirus-1 DNA vaccine induces protective immunity in cattle. J Gen Virol 79:831-839

2. Bins AD, Van den Berg JH, Oosterhuis K, Haanen JB (2013) Recent advances towards the clinical application of DNA vaccines. Neth J Med 71:109-117

3. Van Drunen Littel-van den Hurk S, Braun RP, Lewis PJ, Karvonen BC, Babiuk $L A$, Griebel PJ (1999) Immunization of neonates with DNA encoding a bovine herpesvirus glycoprotein is effective in the presence of maternal antibodies. Viral Immunol 12(1):67-77. https://doi.org/10.1089/vim.1999.12. 67

4. 11713825. SHR and review of D vaccine products (2000) Regulation and review of DNA vaccine products. Dev Biol 104:57-62

5. Dunham S (2002) The application of nucleic acid vaccines in veterinary medicine. Res Vet Sci 73(1):9-16. https://doi.org/10.1016/S0034-5288(02 )00032-2

6. Babiuk LA, Pontarollo R, Babiuk S, Loehr B, Drunen Littel-van den Hurk S (2003) Induction of immune responses by DNA vaccines in large animals. Vaccine 21(7-8):649-658. https://doi.org/10.1016/s0264-410x(02)00574-1

7. Adler B, Bulach D, Chung J, Doughty S, Hunt M, Rajakumar K, Serrano M, van Zanden A, Zhang YRC (1999) Candidate vaccine antigens and genes in Pasteurella multocida. J Biotechnol 73(2-3):83-90. https://doi.org/10.1016/ s0168-1656(99)00111-x

8. Wu JR, Shien JH, Shieh HK, Chen CFCP (2007) Protective immunity conferred by recombinant Pasteurella multocida lipoprotein E (PIpE). Vaccine 25(21):4140-4148. https://doi.org/10.1016/.jvaccine.2007.03.005

9. Mostaan S, Ghasemzadeh A, Ehsani P, Sardari S, Shokrgozar MA, Abolhassani M et al (2020) In silico analysis of Pasteurella multocida PlpE protein epitopes as novel subunit vaccine candidates. Iran Biomed J 25(1):41-46. https://doi.org/10.29252/ibj.25.1.41

10. Basagoudanavar SH, Singh DK, Varshney BC (2006) Immunization with outer membrane proteins of Pasteurella multocida (6:B) provides protection in mice. J Vet Med A Physiol Pathol Clin Med 53(10):524-530. https://doi.org/1 $0.1111 / j .1439-0442.2006 .00900 . x$

11. Lee J, Kim YBKM (2007) Outer membrane protein $\mathrm{H}$ for protective immunity against Pasteurella multocida. J Microbiol 45:179-184

12. Muhammad Azam F, Zamri-Saad M, Abdul Rahim R, Chumnanpoen P, Ekobon T, Othman S (2020) Antigenic outer membrane proteins prediction of Pasteurella multocida serotype B:2. Asia Pac J Mol Biol Biotechnol 28:102116. https://doi.org/10.35118/apjmbb.2020.028.4.09

13. Tan HY, Nagoor NHSS (2010) Cloning, expression and protective capacity of $37 \mathrm{kDa}$ outer membrane protein gene (ompH) of Pasteurella multocida serotype B:2. Trop Biomed 27(3):430-441

14. Haynes AM, Fernandez M, Romeis E, Mitjà O, Konda KA, Vargas SK, Eguiluz M, Caceres CF, Klausner JD, Giacani L (2021) Transcriptional and immunological analysis of the putative outer membrane protein and vaccine candidate TPRL of Treponema pallidum. PLoS Negl Trop Dis 15(1): 1-21. https://doi.org/10.1371/journal.pntd.0008812

15. Luo Y, Glisson JR, Jackwood MW, Hancock REW, Bains M, Cheng IHN et al (1997) Cloning and characterization of the major outer membrane protein gene (ompH) of Pasteurella multocida X-73. J Bacteriol 179(24):7856-7864. https://doi.org/10.1128/jb.179.24.7856-7864.1997

16. Nefedchenko AV, Glotova TI, Glotov AG, Ternovoy VASA (2017) Prevalence of different OmpH-types among Pasteurella multocida isolated from lungs of calves with respiratory problems. Microb Pathog 104:184-189. https://doi. org/10.1016/j.micpath.2017.01.034

17. Dabo SM, Confer A, Montelongo M, York PWJ 3rd. (2008) Vaccination with Pasteurella multocida recombinant OmpA induces strong but nonprotective and deleterious Th2-type immune response in mice. Vaccine 26(34):4345-4351. https://doi.org/10.1016/j.vaccine.2008.06.029 
18. Register KB, Sacco REBS (2007) Immune response in mice and swine to DNA vaccines derived from the Pasteurella multocida toxin gene. Vaccine 25(32):6118-6128. https://doi.org/10.1016/j.vaccine.2007.05.028

19. Qiang G, Ming C, Ming-fu N (2011) Out membrane protein DNA vaccines for protective immunity against virulent avian Pasteurella multocida in chickens. Environ Sci 8:723-729. https://doi.org/10.1016/j.proenv.2011.10.110

20. Muenthaisong A, Nambooppha B, Rittipornlertrak A, Tankaew P, Varinrak T, Muangthai K, Atthikanyaphak K, Sawada T, Sthitmatee N (2020) An intranasal vaccination with a recombinant outer membrane protein $\mathrm{H}$ against haemorrhagic septicemia in swamp buffaloes. Vet Med Int 2020:1-7. https://doi.org/10.1155/2020/3548973

21. Chelliah S, Velappan RD, Lim KT, Swee CWK, Nor Rashid N, Rothan HA, Kabir N, Ismail S (2020) Potential DNA vaccine for haemorrhagic septiceamia disease. Mol Biotechnol 62(5):289-296. https://doi.org/10.1007/s12033-02000244-0

22. Hassan GM, El-Feky ZA, Eissa EA, Teleb AA (2016) Rapid diagnosis of virulent Pasteurella multocida isolated from farm animals with clinical manifestation of pneumonia respiratory infection using 16S rDNA and KMT1 gene. Asian Pacific J Trop Dis 6(1):21-26. https://doi.org/10.1016/S2222-1808(15)60979-3

23. Tillett D, Neilan BA (2000) Xanthogenate nucleic acid isolation from cultured and environmental cyanobacteria. J Phycol 36(1):251-258. https://doi.org/1 0.1046/j.1529-8817.2000.99079.x

24. Li JF, Li L, Sheen J (2010) Protocol: a rapid and economical procedure for purification of plasmid or plant DNA with diverse applications in plant biology. Plant Methods 6(1):2-8. https://doi.org/10.1186/1746-4811-6-1

25. Tamura K, Dudley J (2007) Masatoshi Nei SK. MEGA4: molecular evolutionary genetics analysis (MEGA) software version 4.0. Mol Biol Evol 24(8):45961599. https://doi.org/10.1093/molbev/msm092

26. Leitner G, Yadlin B, Glickman A, Chaffer M, Saran A (2000) Systemic and local immune response of cows to intramammary infection with Staphylococcus aureus. Res Vet Sci 69(2):181-184. https://doi.org/10.1053/ rvsc.2000.0409

27. Confer AW, 崔宇红 (1993) Immunogens of Pasteurella. Vet Microbiol 37(34):353-368. https://doi.org/10.1016/0378-1135(93)90034-5

28. Pati US, Srivastava SK, Roy SC, More T (1996) Immunogenicity of outer membrane protein of Pasteurella multocida in buffalo calves. Vet Microbio 52(3-4):301-311. https://doi.org/10.1016/S0378-1135(96)00066-1

29. Davies RL, MacCorquodale R, Baillie SCB (2003) Characterization and comparison of Pasteurella multocida strains associated with porcine pneumonia and atrophic rhinitis. J Med Microbiol 52(1):59-67. https://doi. org/10.1099/jmm.0.05019-0

30. Jabbari AR, Esmaelizad M, Jula GM (2006) Molecular typing of avian Pasteurella multocida isolates from Iran by PCR-RFLP of OmpH gene, vol 3. EPC 2006 - 12th Eur Poult Conf, Verona, p paper 241

31. Singh AP, Singh S, Ranjan R, Gupta SK, Singh VP, Sharma B (2010) Molecular heterogeneity of plpE gene in Indian isolates of Pasteurella multocida and expression of recombinant PlpE in vaccine strain of $\mathrm{P}$. multocida serotype $\mathrm{B}$ : 2. J Vet Sci 11(3):227-233. https://doi.org/10.4142/jvs.2010.11.3.227

32. Liu R, Chen C, Cheng L, Lu R, Fu G, Shi S et al (2017) Ducks as a potential reservoir for Pasteurella multocida infection detected using a new $\mathrm{rOmpH}$ based ELISA. J Vet Med Sci 79(7):1264-1271. https://doi.org/10.1292/jvms.170124

33. Abbas AM, Abd El-Moaty DAM, Zaki ESA, El-Sergany EF, El-Sebay NA, Fadl HA et al (2018) Use of molecular biology tools for rapid identification and characterization of Pasteurella spp. Vet World 11(7):1006-1014. https://doi. org/10.14202/vetworld.2018.1006-1014

34. Hatfaludi T, Al-Hasani K, Boyce JDAB (2010) Outer membrane proteins of Pasteurella multocida. Vet Microbiol 44(1-2):1-17. https://doi.org/10.1016/j. vetmic.2010.01.027

35. Antony PX, Nair GK, Jayaprakasan V, Mini M, George S (2006) A simple protocol for amplification of genes from inactivated oil adjuvant fowl cholera vaccine. Int J Poult Sci 5(7):623-626. https://doi.org/10.3923/ijps.2 006.623 .626

36. Alam Sl, Bansod S, Singh L (2008) Immunization against Clostridium perfringens cells elicits protection against clostridium tetani in mouse model: identification of cross-reactive proteins using proteomic methodologies. BMC Microbiol 8(1):1-7. https://doi.org/10.1186/1471-21808-194

37. Singh S, Singh VP, Cheema PS, Sandey M, Ranjan R, Kumargupta S et al (2011) Immune response to DNA vaccine expressing transferrin binding protein a gene of Pasteurella multocida. Braz J Microbiol 42(2):750-760. https://doi.org/10.1590/\$1517-83822011000200043

38. Singh R, Gupta PK, Rao VDP (2009) Expression and purification of the major outer membrane protein $(\mathrm{OmpH})$ of Pasteurella multocida p52 from Escherichia coli. Vet Arh 79:591-600

39. Bosch M, Garrido ME, Pérez De Rozas AM, Badiola I, Barbé J, Llagostera M (2004) Pasteurella multocida contains multiple immunogenic haemin- and haemoglobin-binding proteins. Vet Microbiol 99(2):103-112. https://doi. org/10.1016/j.vetmic.2003.11.012

40. Al-Hasani K, Boyce J, McCarl VP, Bottomley S, Wilkie I, Adler B (2007) Identification of novel immunogens in Pasteurella multocida. Microb Cell Factories 6(1):1-5. https://doi.org/10.1186/1475-2859-6-3

41. Alberti E, Acosta A, Sarmiento ME, Hidalgo C, Vidal T, Fachado A, Fonte L, Izquierdo L, Infante JF, Finlay CM, Sierra G (1998) Specific cellular and humoral immune response in Balb/c mice immunised with an expression genomic library of Trypanosoma cruzi. Vaccine 16(6):608-612. https://doi. org/10.1016/S0264-410X(97)00228-4

42. Yero CD, Pajón FR, Caballero ME, Cobas AK, López HY, Fariñas MM, Gonzáles BS, Acosta DA (2005) Immunization of mice with Neisseria meningitidis serogroup B genomic expression libraries elicits functional antibodies and reduces the level of bacteremia in an infant rat infection model. Vaccine 23(7):932-939. https://doi.org/10.1016/j.vaccine.2004.07.032

43. Melby PC, Ogden GB, Flores HA, Zhao W, Geldmacher C, Biediger NM, Ahuja SK, Uranga J, Melendez M (2000) Identification of vaccine candidates for experimental visceral leishmaniasis by immunization with sequential fractions of a cDNA expression library. Infect Immun 68(10):5595-5602. https://doi.org/10.1128/IAl.68.10.5595-5602.2000

44. Beltrán PK, Gutiérrez-Ortega A, Puebla-Pérez AM, Gutiérrez-Pabello JA, Flores-Valdez MA, Hernández-Gutiérrez R, Martínez-Velázquez M, Álvarez AH (2011) Identification of immunodominant antigens of Mycobacterium bovis by expression library immunization. Vet J 190(1):181-183. https://doi.org/1 0.1016/j.tvjl.2010.09.021

45. Sthitmatee N, Numee S, Kawamoto E, Sasaki H, Yamashita K, Takahashi N, Kataoka Y, Sawada T (2008) Protection of chickens from fowl cholera by vaccination with recombinant adhesive protein of Pasteurella multocida. Vaccine 26(19):2398-2407. https://doi.org/10.1016/j.vaccine.2008.02.051

46. Bosch M, Tarragó R, Garrido ME, Campoy S, Fernández de Henestrosa AR, Pérez de Rozas AM et al (2001) Expression of the Pasteurella multocida $\mathrm{ompH}$ gene is negatively regulated by the fur protein. FEMS Microbiol Lett 203(1):35-40. https://doi.org/10.1016/S0378-1097(01)00329-9

47. Homayoon M, Tahamtan Y, Kargar M (2020) The comparison detection of cytokines (IL-6 and IL-12) from spleen cells and serums in Balb/c mice after immunization with killed P. multocida vaccines co-formulated with bacterial DNAs as adjuvant. Arch Clin Microbiol 11(1). https://doi.org/10.36648/19898436.11.1.103

48. Praveena PE, Periasamy S, Kumar AA, Singh N (2010) Cytokine profiles, apoptosis and pathology of experimental Pasteurella multocida serotype A1 infection in mice. Res Vet Sci 89(3):332-339. https://doi.org/10.1016/j.rvsc.2 010.04.012

49. Pors SE, Chadfield MS, Sørensen DB, Offenberg H, Heegaard PMH, Bisgaard M, Jensen HE (2011) Pathology, tissue metalloproteinase transcription and haptoglobin responses in mice after experimental challenge with different isolates of Pasteurella multocida obtained from cases of porcine pneumonia. J Comp Pathol 145(2-3):251-260. https://doi.org/10.1016/j.jcpa.2 011.01 .002

50. Ahmad TA, Rammah SS, Sheweita SA, Haroun M (2014) Development of immunization trials against P multocida. Vaccine 32(8):909-917. https://doi. org/10.1016/j.vaccine.2013.11.068

\section{Publisher's Note}

Springer Nature remains neutral with regard to jurisdictional claims in published maps and institutional affiliations. 